\title{
P2P REVOLUTION AND COMMONS PHASE TRANSITION: NOTES ON THE NATURE OF THE REVOLUTION IN THE P2P/COMMONS EPOCH
}

\author{
Michel Bauwens \\ Founder of the Foundation for Peer-to-Peer Alternatives and works in collaboration with a global group of \\ researchers in the exploration of peer production, governance, and property. \\ Criador da Fundação para Alternativas Peer-to-Peer, trabalha em colaboração com um grupo global de pesquisadores \\ na exploração de produção "peer", governança e propriedade.
}

\begin{abstract}
This article aims at analyzing the relation between the concepts of revolution and transition phase. From the P2P and Commons, it is possible to observe: the process of transition emerging from the dominant system, class division and social structures; the crisis of neoliberal capitalism, taking into consideration sustainable production, mutual support economy, and production among peers; new political ways and social mobilization. The conclusion shows the importance of social reconstruction and the relation between local and global.
\end{abstract}

\section{Keywords}

P2P Revolution. Commons Phase Transition. Social Mobilization.

\section{P2P REVOLUÇÃO E A FASE DE TRANSIÇÃO DOS COMUNS: NOTAS A RESPEITO DA NATUREZA DA REVOLUÇÃO NO P2P/ÉPOCA DOS COMUNS}

\begin{abstract}
Resumo
$O$ objetivo do artigo é analisar a relação entre os conceitos revolução e fase de transição. A partir do P2P e do Commons, verifica-se: o processo de transição do sistema dominante, divisão de classes e estruturas sociais; crise do capitalismo neoliberal, levando em consideração a produção sustentável, economia solidária e produção entre pares; novas formas políticas e as mobilizações sociais. Conclui-se mostrando a importância da reconstrução social e a relação entre local e global.
\end{abstract}

Palavras-chave

Revolução P2P. Fase de Transição do Commons. Mobilização Social. 
At the P2P Foundation, we don't use the moniker 'revolution' with much frequency, preferring the concept of phase transition.

In this article, we would like to elucidate the relation between the two concepts.

In my experience, revolution is used in two quite different senses; in a generic sense, it just means a 'big change', like for example when we speak about the Industrial Revolution, this was a long and drawn out process, with many aspects and it would be really difficult to identify with one particular event. Yet at the same time, there is clearly a time when industrial changes emerged in a mostly agrarian context, and a time when it is the industrial processes and forms of organization which are dominant, and the agrarian aspects subsumed under that domination. Clearly, between these two moments, a 'phase transition' has occurred.

Revolution is also used in a much more narrow fashion, which usually refers to a momentous series of concrete events, in which the very organization of power in society changed fundamentally, leading to a wholesale replacement of human personnel, a new different balance of power between social classes, and the like. Paradigmatic examples would be the French and Russian revolutions.

Both types of revolutions occur throughout history, but for many people, at least for those that live more comfortably, the second notion is less attractive. Indeed, it is most often associated with violence, often directed against the very 'leaders' of the first phases of such revolutions, and to boot, usually leads to counter-revolutions. The achievements of such revolutions, their victories, are often also very problematic. Who can unproblematically affirm that the Napoleonic and Soviet regimes for example, were necessarily 'better' than what they replaced; or, that these radical social and political events produces better outcomes than the slower processes which led to similar phase transitions? An additional issue for the 'narrower' meaning of revolution is that for many people, even for those who dislike the presently dominating regime of their time, is that it is not very clear most of the time, what form the new post-revolutionary regime should take, especially if the negative aspects of other attempts are quite clear.

For this and other reasons, we prefer to talk at the P2P Foundation, about phase transition, stressing the process of change from one system to another, without necessarily being able to predict how exactly these changes will occur, especially on the political and social level. But let's be clear, from the historical record, it is pretty clear that such fundamental changes are usually associated with rather deep social convulsions. For example, if we take the deep shift from the 
Roman system to the feudal system, it was characterized by military invasions from foreign tribes, which substantially changed the political leadership in post-Roman regimes. For centuries, Europe was unstable. If we take the changes associated with the Reformation for example, we see similar convulsions and religious civil wars; the change from the Ancien Regime to capitalism was similarly fraught with deep political and social crises. So there is no doubt that a similarly deep transition will be associated with social convulsions, wars, and yes, political and social revolutions. The question is, what kind of forms these will take, and not that we can guarantee a cozy transition.

However, just as the revolutions of feudalism differed fundamentally from the revolutions that created capitalist societies, so the transition to a commons society will take different forms.

In what follows, I explain my view of what those differences could be.

First, what do we mean more precisely, when we talk about a transition towards a postcapitalist, p2p-driven, commons-oriented society?

Here are a few pointers.

In the present dominant form of society and economics, nature is considered to be an infinite resource and the market 'externalizes' environmental concerns. It is based on 'pseudoabundance'. At the same time, the present system attempts to systematically render 'artificially scarce', what is naturally abundant, such as say agricultural processes, but more specifically, knowledge production. In $\mathrm{p} 2 \mathrm{p} / \mathrm{commons}$ processes, the natural abundance of the immaterial commons such as knowledge, software and design, and technical and scientific knowledge, is recognized and shared and made available to all humanity; and it is associated with changes in the mode of production, that insure that production regenerates resources, maintaining ecological and resource stability for coming generations and for the natural world and its beings, of which we are an integral part.

In the present form, corporate entities compete against each other, but within these entities, collaboration, though mostly hierarchically driven, occurs: cooperation is subsumed under competition; in the new form, ethical entrepreneurial coalitions co-create commons with contributory productive communities; and are interlinked around these commons through social charters and open licenses; though they may compete within that sphere of collaboration. In other words, competition is subsumed under collaboration. The value is created and deposited through 
commons, and the economy creates livelihoods around these commons and their contributory communities, and the market creates 'added value' services and products around these commons.

So what we see here in the nature of these changes are a series of qualitative reversals in terms of the operating logic of the system.

These phase transitions are inextricably linked to changes in the nature of economic, social and political power. How should we see that relationship?

The process of past phase transitions has been the following:

1) the existing dominant system increasingly creates systemic crises that it no longer is able to solve.

2) both managerial (ruling), and productive classes (the dominated producers of value for the managerial classes), look for solutions; they do this in varied, fragmented, and pragmatic ways, under the dominance of the older structure; forming 'patterns of response' , or solutions. Gradually, these patterns find themselves, and though they are used by the dominant system, they also represent an alternative logic that is slowly building up and asserting itself. Within the old paradigm a new prefigurative paradigm emerges, which is subsumed under the old logic at first but gradually gains strength.

3) these changes in the modalities of production and value creation and diffusion also create new social structures; an 'exodus' occurs from the old system towards the new system; Roman slaveholders become feudal lords become merchants and industrial capitalists; slaves become serfs become labor. When the tensions between the new and the old are no longer absorbed by the old system, social and political convulsions occur, eventually leading to 'revolutions' in the organization of society.

Today, we see this process clearly at works.

The systemic crisis of global neoliberal capitalism is leading to 3 types of patterned responses:

1) sustainable production which takes into account ecological limits

2) solidarity economy and cooperative forms of organization which stress the need for social justice in terms of value distribution

3) commons oriented peer production and other forms of sharing and openness which operative against the enclosures, artificial scarcities and privatisation of common knowledge. 
These patterns are still fragmented, only exceptionally 'eco-systemic' in their concrete practice, though these alternative eco-systems are definitely emerging and strengthening. What is specifically emerging is a new proto-mode of production in which contributory communities create common knowledge, in which enterpreneurial coalitions create added value on top of the commons in the still capitalist marketplace, and in which for-benefit associations create and maintain common infrastructures of cooperation and production.

What needs to happen, and is starting to happen is that these productive communities, rather than be subject to the logic of extractive value captation by 'netarchical capitalists' (those in the old system which are investing in the new systems for their own benefit); create their own ethical economic vehicles, which allow them to create livelihoods around their commons-creating activities. This represents the necessary convergence, through open cooperativism, of economic forms which respect social justice (the solidarity economy and other forms), with peer production; and on the other hand the equally necessary convergence with sustainability, through for example the 'open source circular economy'.

A important issue today is the relation between the 'prefigurative' forms, i.e. individuals and communities finding alternative systems of value creation that respond and solve the present systemic crisis, with political and social change. The crisis today expresses itself because the traditional emancipatory forces of the industrial society (left parties, unions and the like), are still oriented towards the old paradigm of capital and labor; while the many productive communities have a strong distrust of these older political forms, and new forms are still weak and emergent.

Nevertheless, we see this necessary convergence is also already happening:

1) new political forms are emerging from the new digitally networked production practices, such as the Pirate Parties and others

2) huge social mobilisations have taken place, using the models of peer production in their creation of politics, which has substantially influenced the new political movements that have also grown from this, like Syriza in Greece, and Podemos in Spain. Emblematic may be the city coalition in Barcelona, En Comu, which won the elections, and which is the first political coalition to specifically refer to the common in its new political ideology. Other perhaps even more radical forms are the civic coalitions that have emerged in France, (Saillant), and the UK (Frome), in which allied civic groups directly replace the existing 'political machines'. 
These more political movements have emerged from what were originally anti-political mobilisations but have learned through experience that prefigurative actions and protests cannot produce substantial victories in the context of a hostile state; and that therefore, the state itself has to be tackled and transformed. What is most likely in this evolution is the transformation of the electoral democracies, in which elections have now themselves become enclosures of political power of the people by a professional political class that is operating in a market state form that is dominated by private financial interests that have made real and gradual change impossible. New hybrid forms will combine elections, with associated forms of deliberative and participative democracy, but the political initiative more directly in the hands of the citizenry, and use the 'partner state' model, in which a transformed state will create the necessary civic and technical infrastructures to 'enable and empower individual and collective autonomy'; on the political agenda is the development of public-commons partnerships and the communification of public services, such as for example the example of the Bologna Regulation for the Care of the Urban Commons.

My personal belief is that given the exodus from labor forms of work to those of networked and commons-creating peer producers of the new precarious working class, that a reconstruction of social and political institutions is necessary, based no longer of the declining form of the salariat (which is itself a legal form of subordination), but on the 'commons'. I have elsewhere proposed to create at the local level, Assemblies of the Commons for civic actors and Chambers of the Commons for the new economic actors, to reconstitute institutions of 'commonfare' that can recreate a powerful social force that will in turn reconfigure politics to create powerful 'coalitions for the common(s)', such as En Comu in Barcelona. The Barcelona victory was indeed preceded by precisely such a civic reconstruction by the post-15M activists, which created new participatory forms in the social movements and commons-creating productive communities.

Another important issue to be resolved in this specific phase transition is the relation between the local and the global. The big wave of relocalisation taking place today, through for example the groups reconfiguring the provision of food and energy, is paradoxically itself facilitated by the globally networked technology that is the internet. But most of the time, these local communities using global technology to strengthen local activity, and not necessarily to project global power. 
Today we have global formal civic associations, and through $\mathrm{p} 2 \mathrm{p}$, global open design communities, what is missing is global ethical entepreneurial forms that can operate on a global scale and can form a counterpower to private and extractive multinational corporations. The immediate limitations imposed on the Greek Syriza party also shows the very strong limitations for local and national politics in terms of structural change. Local and national movements are necessary, but not sufficient, and a orientation towards the global commons, through physical global institutions, will be vital, as is their political expression. Lasindias.net has proposed, and we support this vision, the creation of 'phyles', global business eco-systems that sustain the commons and their communities, and the FairCoop project is a first attempt at developing this.

Revolutions in the narrow sense, are organic and often destructive events, not in the control of any particular social force, we can notice the tinder, but we can't know which spark will alight it. It would be unwise to rejoice especially if the alternative social forces and productive systems are still emerging.

Big waves of social revolution has been unsuccessful, like for example the wave of 1848 in Europe, or the wave of 1968; and as for the successes, "be careful what you wish for".

Therefore today, what matters is the reconstruction of prefigurative value-creating production systems first, to make peer production a autonomous and full mode of production which can sustain itself and its contributors; and the reconstruction of social and political power which is associated and informed by this new social configuration. The organic events will unfold with or without these forces, ready or not, but if we're not ready, the human cost might be very steep.

Therefore the motto should be: contribute to the phase transition first; and be ready for the coming sparks and organic events that will require the mobilization of all. 